\title{
Effects of soil type on density of trees and nutritive value of tree leaves in selected communal areas of South Africa
}

\author{
K.E. Ravhuhali ${ }^{1,2 \#}$, V. Mlambo ${ }^{3}$, T.S. Beyene ${ }^{4}$ \& L.G. Palamuleni ${ }^{5}$ \\ ${ }^{1}$ Department of Animal Science, School of Agricultural Sciences, Faculty of Natural and Agricultural Sciences, North- \\ West University, Mmabatho 2735, South Africa. \\ ${ }^{2}$ Food Security and Safety Niche Area, Faculty of Natural and Agricultural Sciences, North-West University, Mmabatho \\ 2735, South Africa. \\ ${ }^{3}$ School of Agricultural Sciences, Faculty of Agriculture and Natural Sciences, University of Mpumalanga, Private Bag \\ x11283, Mbombela 1200, South Africa. \\ ${ }^{4}$ Department of Livestock and Pasture Science, University of Fort Hare, Alice, Eastern Cape, South Africa. \\ ${ }^{5}$ Department of Geography and Remote Sensing, School of Environmental and Health Sciences, Faculty of Natural and \\ Agricultural Sciences, North-West University, Mmabatho 2735, South Africa.
}

(Received 25 March 2019; Accepted 5 January 2020; First published online 16 February 2020)

\begin{abstract}
Copyright resides with the authors in terms of the Creative Commons Attribution 4.0 South African Licence.
See: http://creativecommons.org/licenses/by/4.0/za

Condition of use: The user may copy, distribute, transmit and adapt the work, but must recognise the authors and the South African Journal of Animal Science.
\end{abstract}

\begin{abstract}
This study aimed to describe the distribution and nutritive value of woody species growing in clayloamy and red-brown sand from selected localities of North West, South Africa. Three $2.2 \mathrm{~km}$ transects, radiating from homesteads, which served as replicates, were established at each of four selected grazing areas. Nine $10 \times 10 \mathrm{~m}$ homogenous vegetation units (HVU), $20 \mathrm{~m}$ apart, were marked in each transect. Woody plant density, height and canopy cover (CC), were recorded, and chemical properties and degradability via in vitro ruminal fermentation of harvested leaves were measured. Raisin bush (Grewia flava), Buffalo thorn (Ziziphus mucronata) and Camel thorn (Vachellia erioloba) were the common species across both soil types. Soil type influenced $(P<0.05)$ plant density, $C C$, total tree equivalent $($ TTE) and plant height. Areas with red-brown sandy soil had higher $(P<0.05)$ total plant density $(827.7$ plant/ha), CC $(9.6 \%)$ and TTE (2886.4 TTE/ha) than those with clay-loamy soil. Vachellia erioloba leaves in clay-loamy soil had the highest $(P<0.05)$ crude protein content $(151.2 \mathrm{~g} / \mathrm{kg} \mathrm{DM})$. Leaves of Searsia lancea species that were harvested from both the clay-loamy and red-brown sandy soils had the highest $(P<0.05)$ amounts of condensed tannins (0.915 $\mathrm{AU}_{550} / 200 \mathrm{mg}$ and $0.917 \mathrm{AU}_{550} / 200 \mathrm{mg}$, respectively). Searsia lancea leaves had the lowest $(P<0.05)$ in vitro ruminal nitrogen degradability values in both soil types. The leaves of $Z$. mucronata and $G$. flava leaves have potential as protein supplements for ruminants owing to their higher crude protein content and in vitro ruminal $\mathrm{N}$ degradability.
\end{abstract}

Keywords: canopy cover, feeding value, plant height, semi-arid, species diversity, tree equivalent

\#Corresponding author: Khuliso.ravhuhali@nwu.ac.za

\section{Introduction}

Cattle, sheep and goats are mostly reared on communal rangelands in semi-arid areas where browse species constitute the major feed resource, but may also be a major threat to rangeland productivity. Indeed, impenetrable thickets, consisting mainly of Acacia spp and Dichrostachys cinera, are known to reduce grass cover in the semi-arid areas (Tolsma et al., 1987). Plant distribution in rangelands is affected by factors such as climate, soil type and biotic interactions (human and livestock effects) (Steege et al., 2003; Okiror et al., 2012). These factors also determine which plant species are filtered into the local community, and thus have a direct effect on the ecological balance of the rangeland.

Woody plants have appropriate agronomic characteristics to contribute browse products of high nutritional value for ruminants reared in semi-arid communal rangelands. They are known to maintain higher levels of protein and minerals during growth than grasses (Shelton, 2004). Utilization of these species by livestock in most areas has been low despite the known benefits such as reducing bush encroachment and improving animal performance in semi-arid areas. The presence of anti-nutritional factors in tree foliage has 
been shown to contribute to low voluntary intake of browse products (Mlambo et al., 2015). Establishment of the nutrient concentration and other nutritive value indicators of herbage from natural browse plants is essential for efficient and sustainable production of animals off the veld (Tefera et al., 2008). Furthermore, assessment of the distribution and status of native vegetation is essential for sustainable management of these ecological systems. There is also a need for continuous screening of browse trees to identify those with potential for animal feeding in order to increase the productivity of ruminants. Despite the heavy dependency on rangelands by communal livestock, little research has been done on the distribution and nutritive value of woody species in most communal areas around the country. Indeed, the distribution and potential nutritive value of woody species in most communal rangelands of North West have not been studied. Thus, the objective of the study was to determine the distribution and nutritive value of browse trees in selected localities of that province.

\section{Material and Methods}

The study was conducted on four communal rangelands (grazing areas) in Ngaka Modiri Molema district of the province of North West, South Africa. These sites were selected because field observations before starting with the trials had shown that they were highly overgrazed or mismanaged and spanned two soil types. The two sites with clay-loamy soil type sites were Tsetse (S25 44.776 E025 40.533$)$ and Six

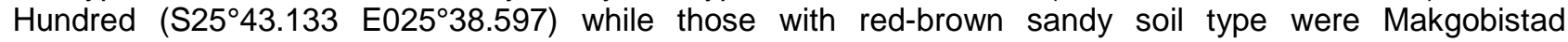

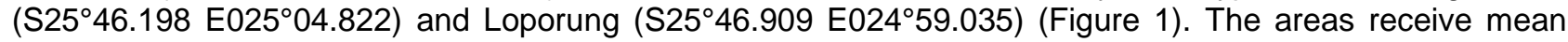
annual rainfall ranging from 400 to $450 \mathrm{~mm}$, whereas the mean annual temperature varies between $2{ }^{\circ} \mathrm{C}$ and $36{ }^{\circ} \mathrm{C}$. The landscape in Tsetse and Six-hundred is undulating rather than flat and ranges in altitude from 1296 to $1309 \mathrm{~m}$ above sea level with dry highveld grassland vegetation (Mucina \& Rutherford, 2006). The landscape in Makgobistad and Loporung is also undulating and ranges in altitude from 1117 to $1182 \mathrm{~m}$ above sea level with Eastern Kalahari Bushveld vegetation. Most ruminants that graze in these areas are goats and cattle.

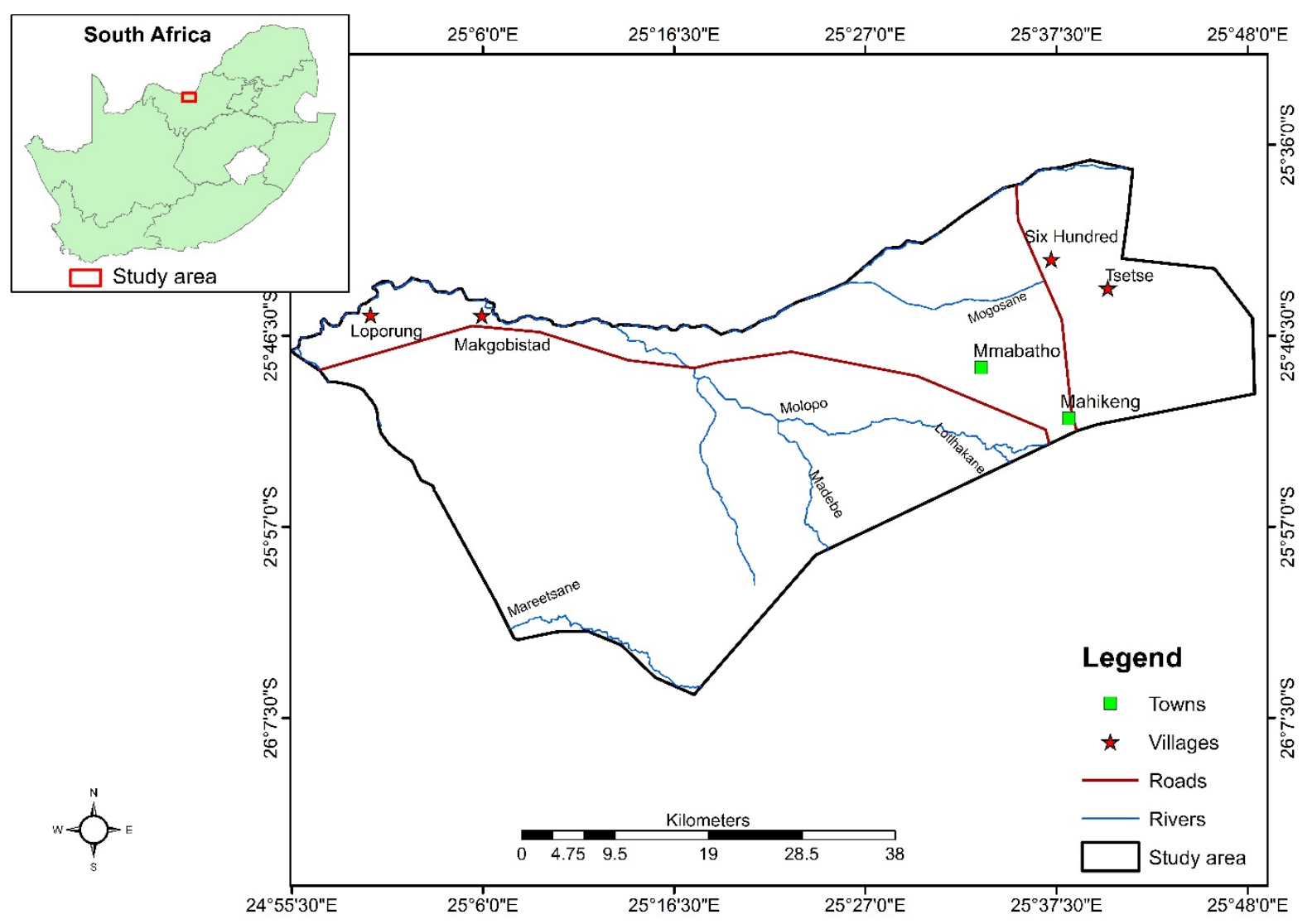

Figure 1 Map locating the Loporung, Makgobistad, Six Hundred and Tsetse study sites in North West, South Africa 
Data collection was conducted between January and May 2015 using three $2.2 \mathrm{~km}$ transects, which served as replicates. These radiated from homesteads at each of the selected grazing areas. The three transects were placed at least $200 \mathrm{~m}$ from each other. Along each transect, points were marked at intervals of $500-700 \mathrm{~m}$ from the homesteads to form nine sampling sub-transects. Three $10 \times 10 \mathrm{~m}$ homogenous vegetation units were marked in each sub-transect, $20 \mathrm{~m}$ apart, resulting in a total of $27 \mathrm{HVUs}$ per grazing area, from which density, height, canopy diameter of individual woody plants and chemical composition of leaves were determined. The identification of the plant was carried out as described by Van Wyk et al. (2012). The chemical composition of dominant species (composition of above 13\%) and common species (composition of above 3\%) leaves was also determined. All rooted live woody plants were recorded and counted in each HVU. Within each sub-plot, trees were identified, counted and classified based on height as seedlings $(0-1 \mathrm{~m})$, young shrubs $(1-1.5 \mathrm{~m})$, mature shrubs $(1.5-2 \mathrm{~m})$, young trees $(2-3 \mathrm{~m})$, and mature trees $(>3 \mathrm{~m})$. Within each HVU, the canopy diameter of every woody plant species was measured along two axes (length $(\mathrm{L})$ and width $(\mathrm{W})$ perpendicular to each other. Determination of the CC percentage was done using this equation (Blozan, 2006):

$$
\text { Canopy cover }=\left(\frac{\pi}{2} L+\frac{\pi}{2} W\right) / 300 \mathrm{~m} \times 100
$$

When an overlap was encountered between the canopies of adjacent woody plants, the length of the overlap was subtracted from the length or width of either of the plants. Total tree equivalent was calculated by dividing the total tree length by 1.5 .

Leaves were harvested from common browse tree species (above 3\% distribution) (five individual trees per species) that were identified from each grazing communal area. Leaf samples were oven dried at $60{ }^{\circ} \mathrm{C}$ until constant weight, and ground to pass through a 2-mm sieve. Milled samples were stored in airtight plastic bags pending chemical analysis and in vitro ruminal fermentation. Dry matter (DM) and organic matter (OM) content were determined according to method 973.18 (AOAC, 2012), whereas nitrogen (N) content was determined following the standard macro-Kjeldahl (AOAC, 2012 method 976.06) and crude protein (CP) was equal to $6.25 * \mathrm{~N}$. The procedures described by Van Soest et al. (1991) were used to determine neutral detergent fibre (NDF), acid detergent fibre (ADF) and acid detergent lignin (ADL). Sodium sulphide and heat-stable bacterial $\alpha$-amylase were used for NDF analysis. The fibre fractions were expressed inclusive of residual ash. Soluble phenolics and soluble condensed tannins were assayed according to Makkar (2003) and Porter et al. (1986), respectively. Soluble phenolics were expressed in $\mu \mathrm{g}$ of tannic acid equivalents $(\mu \mathrm{g}$ TAE). The soluble condensed tannin concentration results were reported as absorbance units (AU) per 200 mg sample.

In vitro ruminal DM and $\mathrm{N}$ degradation of browse species leaves were determined using the ANKOM Daisy" incubator (ANKOM Technology Corp, Fairport, NY). Rumen fluid was collected from a one Bonsmara cow that was fed a diet containing lucerne (912.6, 773.5, 459.6, 335.9, 91.9, 221.4, and $139.1 \mathrm{~g} / \mathrm{kg}$ DM for DM, OM, NDF, ADF, ADL, CP, and ash, respectively) and buffalo grass (959.7, 918.2, 738.2, 388.3, 80.76, 60.75 , and $41.5 \mathrm{~g} / \mathrm{kg}$ for DM, OM, NDF, ADF, ADL, CP, and ash, respectively). Zero-hour samples of the leaves from each species were soaked in warm $\left(39^{\circ} \mathrm{C}\right)$ water for 20 minutes and then dried at $105^{\circ} \mathrm{C}$. Additional samples were inoculated in rumen fluid, withdrawn at 24, 36, and 48 hours, washed with cold water for 20 minutes and dried at $105{ }^{\circ} \mathrm{C}$ to determine DM degradability. To determine $\mathrm{N}$ degradability, $\mathrm{N}$ in DM residues was determined by the macro-Kjeldahl method (AOAC, 2012 method 976.06) and the loss in $\mathrm{N}$ from incubated substrate was estimated as degradable $\mathrm{N}$. The fistulated animal was cared for according to the guidelines of the institution and of the Federation of Animal Science Societies (FASS, 2010) for the care and use of agricultural animals in research and teaching. Ethical approval was obtained from North-NorthWest University Animal Research Ethics Committee, approval number NWU-00126-13-A9.

Effects on total tree plant densities, CC, height class distribution and TTE were evaluated using a oneway analysis of variance (SAS, 2010). The analysis was designed to test the effect of soil type on parameters according to this general linear model:

$$
Y i j=\mu+S i+\varepsilon i j
$$

Where: $Y_{i j}$ is the response variable (height, total tree plant density, CC, height class distribution and TTE), $\mu$ is overall mean,

$S_{i}$ is the effect of soil type, and

$\varepsilon i j$ was the error term associated with observation $i j k$, assumed to be normally and independently distributed.

Chemical composition and in vitro ruminal fermentation data were analysed (SAS, 2010) to test the effect of plant species (four species) and soil type (two soil types represented by two sites each) according to the following general linear model: 


$$
Y i j k=\mu+P i+S j+(P \times S) i j++\varepsilon i j k
$$

Where: $Y_{i j k}$ is the response variable (density of common species, chemical composition and in vitro ruminal degradability),

$\mu$ is overall mean,

$P_{i}$ is the effect of plant species,

$S_{j}$ is the effect of soil type,

$(\mathrm{P} \times \mathrm{S})_{\mathrm{ij}}$ is the interaction between plant species and soil type, and

$\varepsilon i j k$ is the error term associated with observation ijk and assumed to be normally and independently distributed.

Differences among means were assessed by the method of least significant differences at $P=0.05$ ).

\section{Results}

A total of 21 browse species were identified across the two soil types (Tables 1). Soil type and tree species interacted to influence $(P<0.05)$ plant density (Table 2). Grewia flava and Vachellia erioloba dominated, while Ziziphus mucronata was common in both clay-loamy and red-brown sand soils. Grewia flava plants were the most abundant species $(P<0.05)(168.5$ species/ha) in red-brown sand soil. The density of $V$. erioloba tree species tended to be higher (75.9 plants/ha) in red-brown sand soil compared with clay-loamy soil (48.2 plants/ha).

Table 1 Scientific and vernacular names, growth forms, browse values of woody plants identified in the Loporung, Makgobistad, Six Hundred and Tsetse study sites in North West, South Africa

\begin{tabular}{|c|c|c|c|c|}
\hline Scientific name & Common or vernacular name ${ }^{1}$ & $\begin{array}{c}\text { Growth } \\
\text { form }^{2}\end{array}$ & Herbivores & Preferred plant part \\
\hline Bosia albitrunca & Motlopi (Tsw) & $\mathrm{T}$ & Cattle and game & Leaves \\
\hline Dichrostahys cinerea & Moselesele (Tsw) Sickle bush & $\mathrm{S}$ & Goats & Leaves \\
\hline Euclea divinorum & Motlhakola (Tsw)) & $\mathrm{S}$ & - & - \\
\hline Grewia flava & Moretwa (Tsw) Brandy bush & $\mathrm{T}$ & Goats and game & Leaves and fruits \\
\hline Grewia monticola & Moretlwa (Tsw) & $\mathrm{S}$ & Goats & Leaves \\
\hline Grewia hexamita & Mukunukunu (V) & $\mathrm{S} / \mathrm{T}$ & Goats/cattle/ sheep & Leaves \\
\hline Gymnosporia Buxifolia & Motlhonu (Tsw) & $\mathrm{S}$ & - & - \\
\hline Melia azedarach & Muserenga (V) & $\mathrm{T}$ & Cattle and goats & Leaves \\
\hline Peltophorum africanum & Mosetlha (Tsw) & $\mathrm{T}$ & Goat/cattle & Leaves and pods \\
\hline Searsia lancea & Mosilabele (Tsw) & $\mathrm{T}$ & Cattle, goats, game & Leaves \\
\hline Searsia leptodictya & Mogogobadimo (Tsw)) & $\mathrm{T}$ & Cattle/goat/game & Leaves \\
\hline Senegalia caffra & Morutlhare (Tsw) & $\mathrm{T}$ & Cattle & Leaves \\
\hline Senegalia galpini & Mongangatau (Tsw) & $\mathrm{T}$ & Goats and cattle & Leaves/pods \\
\hline Senegalia mellifera & Monga (Tsw) & $\mathrm{S}$ & Goats and Cattle & Leaves and pods \\
\hline Terminalia Sericea & Mogonono (Tsw) & $\mathrm{T}$ & - & - \\
\hline Vachellia erioloba & Mogotho (Tsw)/Camel thorn & $\mathrm{T}$ & Goats, cattle game & Leaves and pods \\
\hline Vachellia hebaclada & Sikhi (Tsw) & $\mathrm{S}$ & Goats & Leaves/pods \\
\hline Vachellia karoo & Mooka (Tsw) & $\mathrm{S}$ & Goats/Cattle & Leaves/pods \\
\hline Vachellia nilotica & Motsha (Tsw)/ Black thorn & $\mathrm{T}$ & Goats and game & Leaves and pods \\
\hline Vangueria infausta & Mothwanyê or Mmilo (Tsw); & $\mathrm{S} / \mathrm{T}$ & - & - \\
\hline Ziziphus mucronata & Mokgalo (Tsw)/Buffalo thorn & $\mathrm{T}$ & Cattle and goats & Leaves and pods \\
\hline
\end{tabular}

${ }^{1}$ Common or vernacular: Tsw: Tswana; V: Venda

${ }^{2}$ Growth form: T: tree; S: shrub 
Table 2 Effects of soil type on density (number of plants/ha) of selected common tree species in the Loporung, Makgobistad, Six Hundred and Tsetse study sites in North West, South Africa

\begin{tabular}{|c|c|c|}
\hline \multirow{2}{*}{ Tree species } & \multicolumn{2}{|c|}{ Soil type } \\
\hline & Clay-loamy & Red-brown sand \\
\hline Grewia flava & $42.9^{B}$ & $168.50^{\mathrm{aA}}$ \\
\hline Vachellia erioloba & 48.2 & $75.9^{b}$ \\
\hline Searsia lancea & 1.9 & $3.7^{\mathrm{c}}$ \\
\hline Ziziphus mucronata & 11.1 & $9.3^{d}$ \\
\hline Standard error & \multicolumn{2}{|c|}{21.57} \\
\hline
\end{tabular}

Soil type influenced total plant density, CC, plant height class distribution and TTE (Table 3). Sites with red-brown sand soil had higher $(P<0.05)$ total plant density $(827.7$ plant/ha), CC $(9.6 \%)$, and TTE (2886.4 TTE/ha) than those with clay-loamy soil. Areas with red-brown sandy soil had higher density of seedlings (198.15 plants/ha), young shrubs (231.48 plants/ha), mature shrubs (125.93 plants/ha), young trees (170.37 plants/ha), and old trees (92.59 plants/ha) than clay-loamy soil areas.

Table 3 Overall canopy cover (\%), total plant density (number of trees/ha) and total tree equivalents in redbrown sandy and clay-loamy soils species in the Loporung, Makgobistad, Six Hundred and Tsetse study sites in North West, South Africa

\begin{tabular}{lcccccccc}
\hline Soil type & TPD & CC & TTE & Seedlings $(0-1 \mathrm{~m})$ & $\begin{array}{c}\text { YS } \\
(>1-1.5 \mathrm{~m})\end{array}$ & $\begin{array}{c}\text { MS } \\
(>1.5-2 \mathrm{~m})\end{array}$ & $\begin{array}{c}\text { YT } \\
(>2-3 \mathrm{~m})\end{array}$ & $\begin{array}{c}\text { MT } \\
(>3 \mathrm{~m})\end{array}$ \\
\hline \multirow{2}{*}{ CL } & $205.5^{\mathrm{b}}$ & $2.5^{\mathrm{b}}$ & $602.6^{\mathrm{b}}$ & $83.34^{\mathrm{b}}$ & $55.56^{\mathrm{b}}$ & $24.08^{\mathrm{b}}$ & $35.19^{\mathrm{b}}$ & $12.97^{\mathrm{b}}$ \\
RBS & $827.7^{\mathrm{a}}$ & $9.6^{\mathrm{a}}$ & $2886.4^{\mathrm{a}}$ & $198.15^{\mathrm{a}}$ & $231.48^{\mathrm{a}}$ & $125.93^{\mathrm{a}}$ & $170.37^{\mathrm{a}}$ & $92.59^{\mathrm{a}}$ \\
Standard error & 70.01 & 0.76 & 355.21 & 28.99 & 27.99 & 20.07 & 18.08 & 12.57 \\
\hline
\end{tabular}

\footnotetext{
${ }^{\mathrm{ab}}$ Means with common superscripts in the same column do not differ $(P>0.05)$

CL: clay-loamy soil; RBS: red-brown sandu soil; TPD: total plant density; CC: Canopy cover; TTE: total tree equivalent;

YS: yyoung shrubs; MS: mature shrubs; YT: young trees; MT: mature trees
}

Vachellia erioloba leaves harvested from clay-loamy soil areas had higher $(P<0.05) \mathrm{N}$ content $(2.42 \mathrm{~N}$ $\%$ ) compared with those from red-brown soil areas (Table 4). Grewia flava, Z. mucronata and S. lancea leaves harvested from red-brown soil areas had the highest $(P<0.05)$ ADL content compared with the same species harvested from clay-loamy soil sites.

Leaves of Searsia lancea that were harvested from trees in red-brown soil areas had higher $(P<0.05)$ content of soluble phenolics (714.0 $\pm 2.87 \mu \mathrm{g}$ TAE/g DM) compared with those harvested in clay-loamy soil (705.4 $\pm 2.87 \mu \mathrm{g}$ TAE/g DM) (Figure 2). Ziziphus mucronata leaves harvested from both soil types had the lowest $(P<0.05)$ soluble phenolics values compared with all the tree species. In the clay soil, $Z$. mucronata and $S$. lancea leaves had the highest $(P<0.05)$ level of condensed tannins (Figure 3 ). In red-brown sand soil, Z. mucronata $(0.899 \pm 0.034$ AU550/200 mg), G. flava $(0.860 \pm 0.034$ AU550/200 mg) and S. lancea $(0.917 \pm 0.034$ AU550/200 mg) leaves had higher $(P<0.05)$ levels of condensed tannins compared with $V$. erioloba (0.629 \pm 0.034 AU550/200 mg). 


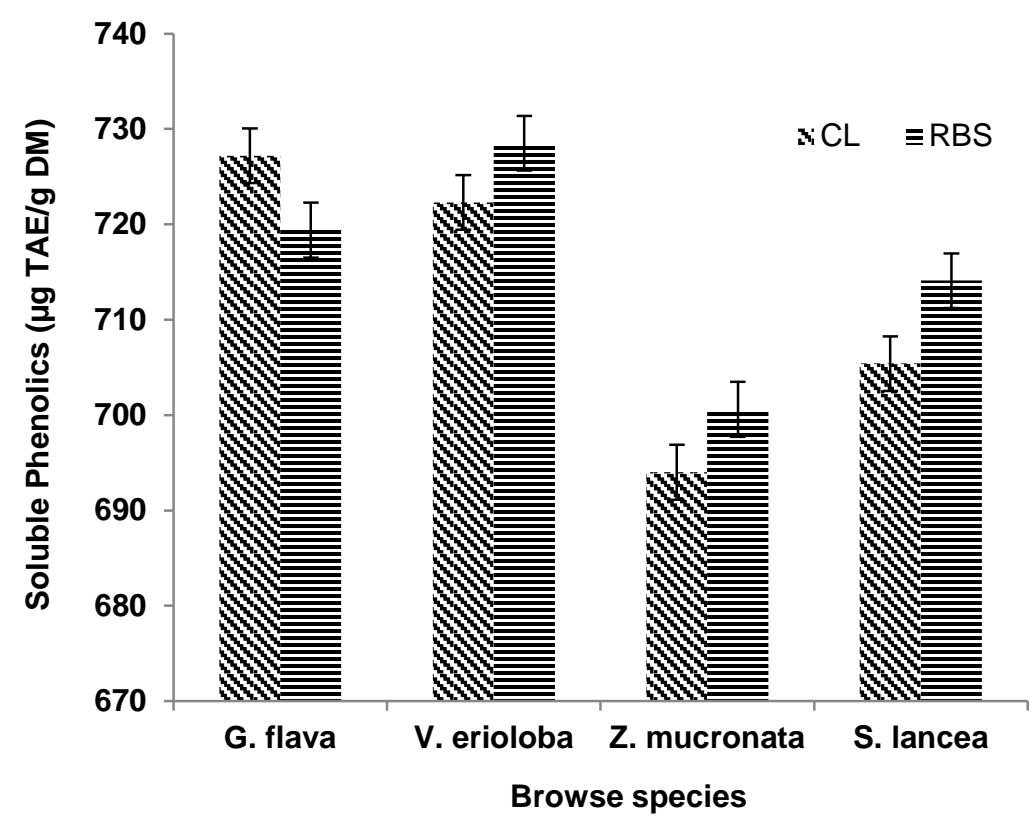

Figure 2 Soluble phenolics ( $\mu$ tannic acid equivalents per g DM) of leaves from common browse species found in clay-loamy soil and red-brown sand soil types

CL: Clay-loamy soil; RBS: red-brown sandy soil

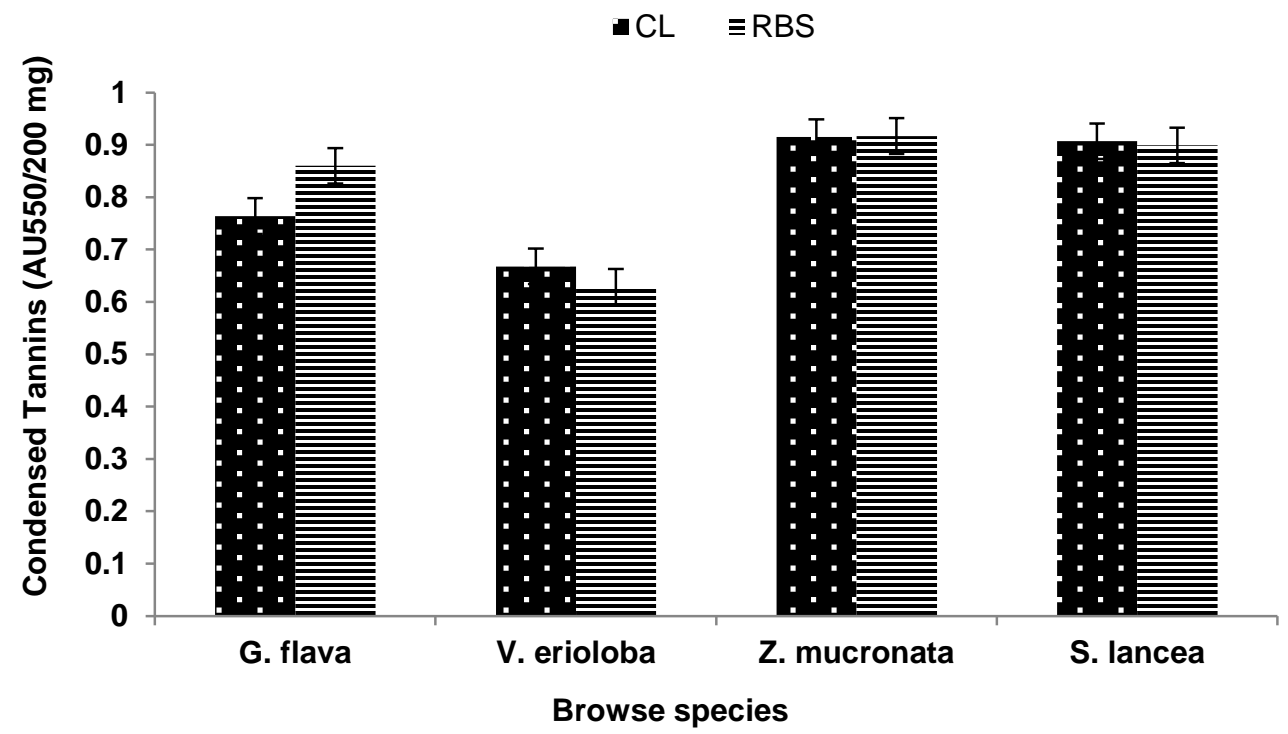

Figure 3 Condensed tannin content $\left(\mathrm{AU}_{550} / 200 \mathrm{mg}\right)$ of leaves from common browse species found in clayloamy soil and red-brown sand soil 


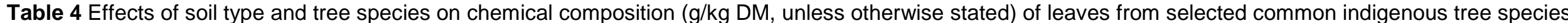
in communal rangelands located in the Loporung, Makgobistad, Six Hundred and Tsetse study sites in North West, South Africa

\begin{tabular}{|c|c|c|c|c|c|c|c|c|c|c|c|c|}
\hline \multirow{2}{*}{ Tree species } & \multicolumn{2}{|c|}{ DM } & \multicolumn{2}{|c|}{$\mathrm{OM}$} & \multicolumn{2}{|c|}{ N (\%) } & \multicolumn{2}{|c|}{ NDF } & \multicolumn{2}{|c|}{ ADF } & \multicolumn{2}{|c|}{ ADL } \\
\hline & $C L$ & RBS & $C L$ & RBS & $C L$ & RBS & $C L$ & RBS & $C L$ & RBS & $C L$ & RBS \\
\hline Grewia flava & $918.9^{\mathrm{a}}$ & $914.8^{\mathrm{b}}$ & $858.0^{b}$ & $850.5^{b c}$ & $2.33^{\mathrm{a}}$ & $2.23^{\mathrm{a}}$ & $513.8^{\mathrm{a}}$ & $520.7^{\mathrm{a}}$ & $335.3^{b}$ & $337.9^{\mathrm{a}}$ & $135.1^{\mathrm{bB}}$ & $161.1^{\mathrm{CA}}$ \\
\hline Vachellia erioloba & $916.2^{\mathrm{abB}}$ & $929.1^{\mathrm{aA}}$ & $855.0^{\mathrm{b}}$ & $868.7^{b}$ & $2.42^{\mathrm{aA}}$ & $1.99^{\mathrm{bB}}$ & $549.3^{\mathrm{a}}$ & $503.9^{\mathrm{ab}}$ & $416.2^{\mathrm{aA}}$ & $357.1^{\mathrm{aB}}$ & $238.7^{\mathrm{aA}}$ & $209.3^{\mathrm{bB}}$ \\
\hline Searsia lancea & $904.1^{\mathrm{b}}$ & $901.7^{c}$ & $822.5^{\mathrm{c}}$ & $832.6^{c}$ & $2.38^{\mathrm{a}}$ & $2.40^{\mathrm{a}}$ & $449.9^{b}$ & $482.9^{\mathrm{abc}}$ & $200.1^{c}$ & $217.2^{c}$ & $79.1^{\mathrm{cB}}$ & $101.5^{\mathrm{dA}}$ \\
\hline Ziziphus mucronata & $920.9^{\mathrm{a}}$ & $926.1^{\mathrm{ab}}$ & $886.7^{\mathrm{a}}$ & $893.4^{\mathrm{a}}$ & $1.56^{\mathrm{b}}$ & $1.61^{\mathrm{c}}$ & $476.5^{\mathrm{abA}}$ & $389.3^{\mathrm{CB}}$ & $404.7^{\mathrm{aA}}$ & $312.8^{\mathrm{bB}}$ & $234.8^{\mathrm{aB}}$ & $278.4^{\mathrm{aA}}$ \\
\hline Standard error & \multicolumn{2}{|c|}{4.14} & \multicolumn{2}{|c|}{6.11} & \multicolumn{2}{|c|}{0.07} & \multicolumn{2}{|c|}{15.62} & \multicolumn{2}{|c|}{7.62} & \multicolumn{2}{|c|}{6.41} \\
\hline
\end{tabular}

abcd In a column, means with common lowercase superscripts do not differ $(P>0.05)$

${ }^{A B C}$ In a row, means with similar uppercase superscripts do not differ $(P>0.05)$

DM: dry matter; OM: organic matter; N: nitrogen; NDF: neutral detergent fibre; ADF: acid detergent fibre; ADL: acid detergent lignin

$\mathrm{CL}$ : clay-loamy soil; RBS: red-brown sandy soil 
Soil type and tree species interacted significantly to influence in vitro ruminal DM and $\mathrm{N}$ degradabilities (Table 5). In clay-loamy soil, $Z$. mucronata leaves had the highest $(P<0.05)$ in vitro ruminal dry matter degradability after 36 hours of incubation. In the red-brown sand soil, $Z$. mucronata $(675.4 \mathrm{~g} / \mathrm{kg})$ leaves had the highest $(P<0.05)$ in vitro ruminal dry matter degradability after 48 hours of incubation. With regard to $\mathrm{N}$ degradability, $V$. erioloba $(431.9 \mathrm{~N} \mathrm{~g} / \mathrm{kg})$ and G. flava $(381.1 \mathrm{~g} / \mathrm{kg} \mathrm{N}$ ) leaves harvested from red-brown sandy soil had the highest $(P<0.05)$ degradability value at 36 hours post incubation compared with all other species in the same soil type. Grewia flava $(493.4 \mathrm{~g} / \mathrm{kg} \mathrm{N})$ leaves harvested from red-brown sand soil had higher $(P<0.05) 48 \mathrm{~h}$ degradability value than leaves from the same species harvested in clay-loamy soil.

Table 5 Effects of species and soil type on in vitro ruminal dry matter $(\mathrm{g} / \mathrm{kg})$ and nitrogen degradability $(\mathrm{g} / \mathrm{kg})$ of leaves from Vachellia erioloba, Grewia flava, Searsia lancea and Ziziphus mucronata trees

\begin{tabular}{|c|c|c|c|c|c|c|c|c|}
\hline \multirow[b]{3}{*}{ Species } & \multicolumn{8}{|c|}{ Incubation time (hours) } \\
\hline & \multicolumn{2}{|c|}{0} & \multicolumn{2}{|c|}{24} & \multicolumn{2}{|c|}{36} & \multicolumn{2}{|c|}{48} \\
\hline & $\mathrm{CL}$ & RBS & $\mathrm{CL}$ & RBS & $C L$ & RBS & $C L$ & RBS \\
\hline \multicolumn{9}{|c|}{ Dry matter degradability } \\
\hline Vachellia erioloba & $94.4^{\mathrm{Bb}}$ & $183.5^{\mathrm{Aa}}$ & $246.1^{\mathrm{cB}}$ & $303.7^{\mathrm{AC}}$ & $304.1^{\mathrm{bB}}$ & $388.6^{\mathrm{aA}}$ & $303.9^{\mathrm{b}}$ & $368.5^{\mathrm{bc}}$ \\
\hline Grewia flava & $105.3^{b}$ & $129.1^{\mathrm{b}}$ & $287.2^{\mathrm{bc}}$ & $308.3^{b}$ & $340.8^{b}$ & $357.8^{\mathrm{b}}$ & $350.8^{\mathrm{bB}}$ & $448.0^{\mathrm{bA}}$ \\
\hline Searsia lancea & $208.7^{\mathrm{a}}$ & $197.9^{\mathrm{a}}$ & $303.7^{\mathrm{b}}$ & $306.5^{b c}$ & $353.6^{\mathrm{b}}$ & $353.2^{\mathrm{b}}$ & $330.6^{\mathrm{b}}$ & $333.2^{c}$ \\
\hline Ziziphus mucronata & $78.8^{\mathrm{b}}$ & $75.2^{\mathrm{c}}$ & $426.0^{\mathrm{a}}$ & $433.1^{\mathrm{a}}$ & $456.0^{\mathrm{a}}$ & $442.7^{\mathrm{a}}$ & $671.0^{\mathrm{a}}$ & $675.4^{\mathrm{a}}$ \\
\hline Standard error & \multicolumn{2}{|c|}{17.1} & \multicolumn{2}{|c|}{15.0} & \multicolumn{2}{|c|}{26.24} & \multicolumn{2}{|c|}{31.52} \\
\hline \multicolumn{9}{|c|}{ Nitrogen degradability } \\
\hline Vachellia erioloba & 156.1 & $183.7^{\mathrm{ab}}$ & 269.2 & $320.8^{a}$ & $398.5^{\mathrm{a}}$ & $431.9^{\mathrm{a}}$ & $323.9^{\mathrm{ab}}$ & $380.8^{a}$ \\
\hline Grewia flava & 158.2 & $230.8^{\mathrm{a}}$ & 298.7 & $319.6^{\mathrm{a}}$ & $335.9^{\mathrm{ab}}$ & $381.1^{\mathrm{a}}$ & $323.8^{\mathrm{abB}}$ & $493.4^{\mathrm{aA}}$ \\
\hline Searsia lancea & 144.6 & $94.4^{\mathrm{b}}$ & 200.7 & $227.5^{a b}$ & $261.9^{b}$ & $266.9^{b}$ & $204.7 b$ & $229.6^{\mathrm{b}}$ \\
\hline Ziziphus mucronata & 160.5 & $146.6^{\mathrm{ab}}$ & 233.5 & $194.8^{\mathrm{b}}$ & $283.1^{\mathrm{b}}$ & $260.3^{b}$ & $402.8^{\mathrm{a}}$ & $447.6^{\mathrm{a}}$ \\
\hline Standard error & \multicolumn{2}{|c|}{32.4} & \multicolumn{2}{|c|}{34.9} & \multicolumn{2}{|c|}{29.7} & \multicolumn{2}{|c|}{46.2} \\
\hline
\end{tabular}

abc Within species, means with common lowercase superscripts in the column do not differ $(P>0.05)$

${ }^{A B C}$ Within soil type, means with common uppercase superscripts in the row do not differ $(P>0.05)$

CL: clay-loamy soil; RBS: red-brown sandy soil

\section{Discussion}

The utility of browse tree species as nutrient sources for various livestock species in communal areas has long been recognized (Aganga et al., 2000). Their leaves have the potential to provide protein and energy to herbivores during extended drought (Lefroy et al., 1992). Despite the obvious utility of these woody species in communal rangelands, little information about their distribution and nutritive value is available in the study area, although livestock productivity in these areas is adversely affected by seasonal feed shortages. This study, conducted in selected communal areas of North West, South Africa, explores and documents the distribution and nutritive value of these woody species across two soil types in a semi-arid climate. Intensive grazing pressure in these areas has resulted in rangeland deterioration and has created an environment that is conducive to the dominance of woody tree species to the detriment of grasses (Moleele et al., 2002). The distribution of tree species was clearly influenced by soil type, with a fewer trees found in the areas with clay-loamy soil compared with those with red-brown sand soil. Clay-loamy soil has a high percentage of silt and clay-sized particles, which contribute to the higher water-holding capacity. This creates a topsoil growth environment that is more conducive to herbaceous shallow-rooted plants that can outcompete woody seedlings. The lower water-holding capacity of the red-brown sandy soil favours the deep-rooted woody plants. Species adaptation can also contribute to the variation seen in the density of tree plants. The density of $G$. flava was higher than other species in the red-brown sandy soil type. Indeed, this species is known to adapt well in rich shallow sandy soils (Mainah, 2001). The similar distribution of $Z$. 
mucronata in this study across soil types could be because this species is adapted to a wide range of soils and is tolerant to a wide range of climates (Orwa et al., 2009).

Woody plant density determines the productivity of available browsable material for livestock and is a useful tool in the control of bush encroachment (Smit, 1989). High density of tree plants is known to be the major cause of reduced grazing capacity of the range. Based on the density of plants per hectare, the study areas were judged to have light bush encroachment.

Different soil types possess different textures and physio-chemical properties (Quan \& Liang, 2017). Areas with red-brown sandy soil had higher density of trees, seedlings, young shrubs, mature shrubs, young trees, and old trees compared with areas with clay-loamy soil. Baker et al. (2004) stressed that sandy soils are generally chemical poor, dominated by primary small particles that feature low structural stability and are easily eroded. Tree growth tends to be rapid on poor soil, subsequently enabling the woody species to become more densely structured (Baker et al., 2004). Osman (2013) attributed soil texture to being responsible for more than $90 \%$ of tree species distribution. In this study, the red-brown sandy soil type areas had a higher percentage of CC than clay-loamy grazing areas. This might have been because the density of tree species was higher on the red-brown sandy soils compared with clay-loamy soils.

The greater abundance of tree species on the red-brown sandy soils of Loporung and Makgobistad could have prohibited the germination of grass species (Lesoli et al., 2013). Only two grass species (Aristida congesta and Eragrostis bicolor) were found to be prevalent in these areas. Karuaera (2011) reported that bush encroachment is the main cause of land degradation and loss of resource productivity. Lack of competition in the veld from herbs and grass promotes bush encroachment (Jordaan \& Roux, 1992). Poor soil type has also been known to contribute to the disappearance of grass species (Morgan \& Connolly, 2013). Woody seedlings compete directly with grasses for topsoil resources. Poor soils can have an influence on the speed of land degradation by gradually reducing the vegetation layer in many semi-arid areas and allowing the emergence of woody species that access subsurface moisture. In addition, droughts and heavy grazing encourage the establishment of woody seedling by reducing grass cover and hence competition for nutrients (Gxasheka et al., 2017).

The leaves from trees that were evaluated in this study were palatable with high nitrogen content, suggesting that they could play a vital role in livestock production as sources of protein. Leaves from Vachellia erioloba grown in red-brown sandy soil had higher $\mathrm{N}$ content compared with those harvested from areas with clay-loamy soil. Differences in soil different texture and physio-chemical properties may contribute to variation in growth, yield and chemical composition of plant species (Hossain et al., 2011; Islam et al., 2011). The $N$ content for $V$. erioloba is comparable with that reported by Mnisi and Mlambo (2016). The $N$ content in $Z$. mucronata leaves on both soil types was $2.4 \% \mathrm{DM}$, which is within the range (1.97 to 2.8\%) reported by Hassen et al. (2009) and Mnisi and Mlambo (2017). Neutral detergent fibre values in this study were high (>500 $\mathrm{g} / \mathrm{kg} \mathrm{DM}$ ) in G. flava and V. erioloba in both soil types. Neutral detergent fibre represents the structural carbohydrate fraction of the plant cell and includes cellulose, hemicellulose and lignin, and is known to be a reliable predictor of voluntary feed intake (Rasby \& Martin, 2017). This suggests that the digestibility of these leaves could be low.

Leaves from Ziziphus mucronata, V. erioloba and S. lancea growing in red-brown sand soil had higher phenolics values than those harvested from trees growing in the clay-loamy soil. This consistent variation in the concentration of phenolics in this study could be attributed to the effect of soil type on the biosynthesis of phenolics. Plants growing in poor soils such as red-brown sand soil are known to accumulate higher levels of secondary plant compounds, some of which have antinutritional effects (D'Mello, 2000). These secondary metabolites function as a chemical defence, which contributes to the herbivore-avoidance mechanism of browse plants (Wessels et al., 2007). In addition, high browsing pressure may induce increased biosynthesis of phenolics as part of an inductive defence mechanism (Bixenmann et al., 2016). It is likely that in areas with red-brown sandy soil there is less grass cover and the woody plants are heavily browsed because they were the only feed resource available. All the browse species, regardless of harvesting site, had soluble phenolic concentration of less than $750 \mu \mathrm{g} \mathrm{TAE} / \mathrm{g} \mathrm{DM}$, which is low and thus may not be harmful to herbivores. Filippich et al. (1991) and Mlambo et al. (2009) pointed out that high amounts of tannins (> 3 $6 \%)$ can have a negative impact on feed intake, ruminal microbial activity and nutrient utilization by the animal.

Ziziphus mucronata leaves had the highest DM degradability of all the species at 36 and 48 hours in both soil types. This finding corroborates that by Mnisi \& Mlambo (2016). Contrary to the findings on $V$. erioloba from the present study, Mabeza et al. (2015) reported higher degradability values after 36 hours of incubation. Low lignin in Z. mucronata (79-102 $\mathrm{g} / \mathrm{kg} \mathrm{DM}$ ) compared with all other species might have been the reason for higher degradability. Lignin is a complex organic polymer that negatively affects the ability of rumen microbes to colonize and break down plant cells, thereby reducing the nutritional value of plants for herbivores. Searsia lancea had the lowest $N$ degradability compared with other species after 36 hours of 
incubation. The presence of secondary compounds such as tannins in this species might be a contributing factor (Moore \& Jung, 2001; Mnisi \& Mlambo, 2016). Tannins are known to bind to protein and other nutrients, thus reducing their availability for ruminal fermentation (Makkar, 2003). However, Z. mucronata leaves had higher condensed tannin content than other browse species, yet still had higher $\mathrm{N}$ degradability at 48 hours. This indicates that condensed tannins from different plants might have different effects on nitrogen degradability (Gemeda \& Hassen, 2015) owing to differences in molecular weight and structure (Mlambo et al., 2004).

\section{Conclusion}

Grewia flava and Vachellia erioloba were the most dominant tree species in all the sites surveyed. In both red-brown sandy and the clay-loamy soils, $Z$. mucronata and G. flava leaves have potential as a source of supplemental protein for ruminants. Utilization of these two species could help reduce bush encroachment while improving survival and productivity of ruminants during the dry seasons.

\section{Acknowledgements}

The authors acknowledge the financial and material support provided by North-West University towards the first author's PhD studies.

\section{Authors' Contributions}

KER conducted the research as a PhD study. VM, TSB and LGP advised the student.

\section{Conflicts of Interest Declaration}

The authors declare there are no conflicts of interest

\section{References}

Aganga, A.A., Adogla-Bessa, T., Omphile, U.J. \& Tshireletso, K., 2000. Significance of browses in the nutrition of Tswana goats. Arch. Zootec. 49, 469-480

AOAC, 2012. Official methods of analysis of AOAC International. 16th ed. Association of Official Analytical Chemists, Arlington, VA, USA.

Baker, T.R., Phillips, O.L., Malhi, Y., Almeida, S., Arroyo, L., Martınez, R.V., 2004. Variation in wood density determines spatial patterns in Amazonian forest biomass. Global Change Biol. 10, 545-562.

Barnes, R.D., 2001. The African Acacias - a thorny subject. S. Afr. Forest. J. 190, 9-18.

Bixenmann, R.J., Coley, P.D., Weinhold, A. \& Kursar, T.A., 2016. High herbivore pressure favors constitutive over induced defense. Ecol. Evol. 6(17), 6037-6049.

Blozan, W., 2006. Tree measuring guidelines of the eastern native tree society. B. Eastern Native Tree Soc. 1, 3-10.

D'Mello, J.F., 2000. Farm animal metabolism and nutrition. Cabi, UK.

FASS, 2010. Guide for the care and use of agricultural animals in research and teaching. Third edition. Federation of Animal Sciences Societies, Illinois, USA.

Filippich, L.J., Zhu, J., Oelrichs, P., Alsamani, M.T., Doig, A.J., Cao, G.R. \& English, P.B., 1991. Hepatotoxic and nephrotoxic principles in Terminalia oblongata. Res. Vet. Sci. 50, 170-177.

Frey, M., 2010. Soils of South Africa. Cambridge University Press, Cape Town, South Africa.

Gemeda, B.S. \& Hassen, A., 2015. Effect of tannin and species variation on in vitro digestibility, gas, and methane production of tropical browse plants. Asian-Aust. J. Anim. Sci. 28, 188-199.

Gxasheka, M., Beyene, S.T., Mlisa, N.L. \& Lesoli, M., 2017. Farmers' perceptions of vegetation change, rangeland condition and degradation in three communal grasslands of South Africa. Trop. Ecol. 58, 217-228.

Hassen, A., Rethman, N.F.G. \& Van Niekerk, W.A., 2009. A note on the potential nutritive value of Ziziphus mucronata (Buffalo Thorn) foliage during different seasons. Afr. J. Range For. Sci. 26, 103-105.

Hossain, M.A., Yamanishi, M., Yara, T., Chibana, S., Akamine, H. \& Tamaki, M., 2011. Growth characteristics, yield and mineral content of redflower ragleaf (Crassocephalum crepidioides (Benth.) S. Moore) at different growth stages, and in dark-red soil, red soil and gray soil in Okinawa. University of the Ryukyus. Sci. Bul. Faculty Agric. 58, 1-11.

Islam, M.M., Karim, A.J.M.S., Jahiruddin, M., Majid, N.M., Miah, M.G., Ahmed, M.M. \& Hakim, M.A., 2011. Effects of organic manure and chemical fertilizers on crops in the radish-stem amaranth-Indian spinach cropping pattern in homestead area. Aust. J. Crop Sci. 5, 1370-1378.

Jordaan, J.J. \& Roux, A.L., 1992. The short-term effect of fire, Boer goats and cattle on the woody component of the Sourish Mixed Bushveld Warmbaths in the Northern Province of South Africa. Agricultural Development Centre, Towoomba.

Karuaera, N.A.G., 2011. Assessing the effects of bush encroachment on species abundance, composition and diversity of small mammals at Neudamm Agricultural farm, Khomas region, Namibia. MSc dissertation, University of Namibia and Humboldt-Universitat zu Berlin.

Lefroy, E.C., Dan, P.R., Wilding, J.H., Wesley-Smith, R.N. \& McGowan, A.A., 1992. Trees and shrubs as sources of fodder in Australia. Agroforest. Syst. 20, 117-139.

Lesoli, M.S., Gyasheka, M, Solomon, T.B. \& Moyo, B., 2013. Integrated plant invasion and bush encroachment management on South African rangelands. Herbicides, current researches and case studies in use. Interchepon, London, UK. 
Mabeza, G., Mpofu, I. \& Masama, E. 2015. Rumen degradability of dry matter and crude protein of diets containing Acacia angustissima, Leucaena trichandra and Calliandra calothyrsus. Int. J. Innov. Res. Dev. 4, 89-93.

Mainah, J., 2001. The distribution and association of Grewia flava with other species in the Kalahari environment. Botswana Notes Rec. 33, 115-127.

Makkar, H.P.S., 2003. Effects and fate of tannins in ruminant animals, adaptation to tannins and strategies to overcome detrimental effects of feeding tannin-rich feeds. Small Rumin. Res. 49, 241-256.

Mlambo, V., Marume, U. \& Gajana, S.C., 2015. Utility of the browser's behavioural and physiological strategies in coping with dietary tannins: Are exogenous tannin-inactivating treatments necessary? S. Afr. J. Anim. Sci. 45, 441-451.

Mlambo, V., Mould, F.L., Smith, T., Owen, E., Sikhosana, J.L.N. \& Mueller-Harvey, I., 2009. In vitro biological activity of tannins from acacia and other tree fruits: Correlations with colorimetric and gravimetric phenolic assays. S. Afr. J. Anim. Sci. 39, 131-143.

Mlambo, V., Smith, T., Owen, E., Mould, F.L., Sikosana, J.L.N. \& Mueller-Harvey, I., 2004. Tanniniferous Dichrostachys cinerea fruits do not require detoxification for goat nutrition: In sacco and in vivo evaluations. Livest. Prod. Sci. 90, 135-144.

Mnisi, C. M. \& Mlambo, V., 2017. Influence of harvesting site on chemical composition and potential protein value of Acacia erioloba, A. nilotica and Ziziphus mucronata leaves for ruminants. J. Anim. Physiol. Anim. Nutr. 101, 9941003.

Moleele, N. M., Ringrose, S., Matheson, W. \& Vanderpost, C., 2002. More woody plants? The status of bush encroachment in Botswana's grazing areas. J. Environ. Manage. 64, 3-11.

Moore, K.J. \& Jung, H.J., 2001. Lignin and fiber digestion. J. Range Manage. 54, 420-430.

Morgan, J.B. \& Connolly, E.L., 2013. Plant-soil interactions: Nutrient uptake. Nature Educ. Knowl. 4(8), 2.

Mucina, L. \& Rutherford, M.C., 2006. The vegetation of South Africa, Lesotho and Swaziland. South African National Biodiversity Institute, Pretoria, South Africa.

Okiror, P., Chono, J., Nyamukuru, A., Lwanga, J.S., Sasira, P. \& Diogo, P., 2012. Variation in woody species abundance and distribution in and around Kibale National Park, Uganda. ISRN Forestry Article ID 490461: 1-9.

Orwa, C., Mutua, A., Kindt, R., Jamnadass, R. \& Anthony, S., 2009. Agroforestree database: A tree reference and selection guide. Version 4.0. World Agroforestry Centre, Kenya.

Osman, K.T., 2013. Forest soil: Properties and management; Physical properties of soils. Springer Berlin. Heidelburg.

Porter, L.J., Hirstich, L.N. \& Chan, B.G., 1986. The conversion of procyanidins and prodelphinidins to cynidin and delphinidin. Phytochemistry. 25, 223-230.

Quan, M. \& Liang, J., 2017. The influences of four types of soil on the growth, physiological and biochemical characteristics of Lycoris aurea (L' Her.) herb. Sci. Rep. 7, 1-8.

Rasby, R. \& Martin, J., 2017. Understanding feed analysis. University of Nebraska-Lincoln. https://beef.unl.edu/learning/feedanalysis.shtml. Accessed December 2017.

SAS, 2010. Statistical Analysis System user guide: Statistics. Version 9.3. SAS Institute, Cary, NC, USA.

Shelton, A.L., 2004. Variation in chemical defences of plants may improve the effectiveness of defence. Evol. Ecol. Res. 6, 709-726.

Smit, G.N., 1989. Quantitative description of woody plant communities: Part I. An approach. J. Grassl. Soc. S. Afr. 6, 186-191.

Steege, H.T., Pitman, N., Sabatier, D., Castellanos, H., Van Der Hout, P., Daly, D.C., Silveira, M., Phillips, O., Vasquez, R., Van Andel, T., Duivenvoorden, J., De Oliveira, A.A., Ek, R., Lilwah, R., Thomas, R., Van Essen, J., Baider, C., Maas, P., Mori, S., Terborgh, J., Vargas, P.N., Mogollon, H. \& Morawetz, W., 2003. A spatial model of tree $\alpha-$ diversity and tree density for the Amazon. Biodivers. Conserv. 12, 2255-2277.

Tefera, S., Mlambo, V., Dlamini, B.J, Dlamini, A.M., Koralagama, K.D.N. \& Mould, F.N., 2008. Chemical composition and in vitro ruminal fermentation of common tree foliage in the semi-arid rangelands of Swaziland. Anim. Feed Sci. Technol. 142, 99-110.

Tolsma, D.J., Ernst, W.H.O., Verweij, R.A. \& Vooijs, R., 1987. Seasonal variation of nutrient concentrations in a semi-arid savannah ecosystem in Botswana. J. Ecol. 75, 755-770.

Van Soest, P.J., Robertson, J.B. \& Lewis, B.A., 1991. Methods of dietary fibre, neutral detergent fibre and non-starch polysaccharides in relation to animal nutrition. J. Dairy Sci. 74, 3583-3597.

Van Wyk, B., Van Wyk, B.E. \& Van Wyk, P., 2012. Photo guide to trees of South Africa. Briza, Pretoria, South Africa.

Walthert, L. \& Meier, E.S., 2017. Tree species distribution in temperate forests is more influenced by soil than by climate. Ecol. Evol. 7, 9473-9484.

Wessels, D.C.J., Van der Waal, C. \& de Boer, W.F., 2007. Induced chemical defences in Colophospermum mopane trees. Afr. J. Range For. Sci. 24, 141-147. 